\title{
The Transformation of Human Rights in the Information Society Connected with the Formulation of the «Rigt to be Forgotten» by the European Court of Justice
}

\author{
S. N. Revina ${ }^{1}$ \\ A. L. Zaharov² \\ 1. Samara State University of Economics, Russia, 443090, Samara, 141, Sovetskoi Armii Street
2. Samara State University of Economics, Russia, 443090, Samara, 141, Sovetskoi Armii Street
Correspondence: S. N. Revina, Samara State University of Economics, 443090, Russia, Samara, 141, Sovetskoi Armii Street
E-mail: 29.revina@mail.ru
}

Doi:10.5901/mjss.2015.v6n6s3p399

\begin{abstract}
Actuality of this research work. Human rights and freedoms - are main concepts of rights in modern Russia. Lack of scientific development of "new" human rights in new "digital measurement", information society holds back development of applied research, including the matters of enforcement, improvement of law-making, efficiency improvement of legal regulation. Due to the fact that "the right to oblivion" was formulated by European Court of Human Rights less than a year ago, in Russia there is no comprehensive legal research on this issue. In fact, in our country a new direction of jurisprudence - legal regulation of technology and protection of private data are being formed. It is not a secret that in the United States, these issues are allocated to a separate specialization for lawyers. Russia is at the beginning of this path. The targets of this research. The target of this research is to study the concept and essence of "the right to oblivion", to deepen the theoretical knowledge of human rights and freedoms, as well as to attract scientists, theorists and practicing lawyers' attention to this issue. The target is concretized in tasks. The authors had the following targets: - To explore the essence of "the right to oblivion", its characteristics, analyze its purpose; - To identify authors' attitude to a number of controversial issues that have arisen in the course of this research work; - Explore ways and means to improve legal regulation. Conclusions. "The right to oblivion" is a new inalienable human right that needs identifying, understanding, and formulation. Legal regulation of this right in Russia is at the stage of formation and is imperfect. It is necessary to increase awareness of the Russian legal science, legislature and judiciary to this problem. It is necessary to develop a general policy with regard to "the right to oblivion", accurately reflect the position in law and judicial practice. The authors analyzed the new phenomenon in Russian law - "the right to oblivion" and analyzed the nature and problems of legal regulation of this important right in information society.
\end{abstract}

Keywords: human rights, "the right to oblivion", the right to privacy, freedom of speech.

\section{Introduction}

Addressing to problems of human rights and freedoms has been illustrated by many authors such as S. S. Alekseev, M. V. Baghlai, M. I. Baytin, V. V. Bolgova, V. M. Vedyahin, L. I. Glukhareva, V. A. Kartashkin, E. A. Lukasheva, V. V. Lapaeva, A. V. Khovanskaya and others. However, not all aspects of this problem have been analyzed. The analysis of existing research works shows a lack of special works, which can refer the reader to "the right to oblivion". In fact, the whole normative and theoretical basis of this research is based on case judicial decisions and periodicals, as well as distributing analytical materials for discussion in the Public Chamber of the Russian Federation. But our life dictates its own rules, and the main task of the lawyer is to identify trends in development of public relations and to consolidate them into law. Living in the era of the Internet, information society requires creation of adequate legal regulation of this space, as well as the related human rights and freedoms in order to protect and develop them on the basis of the advanced scientific legal concept.

\section{Methodology}

The methodological basis of the work is dialectical materialist knowledge of objective reality. On this basis, the authors defined the objectivity of human rights and freedoms, and approved their cognition. The authors also used such techniques as: logical method, analysis and synthesis, systematic method, modeling method, comparative law, and others, and they (the authors) proceeded from the fact that each of these methods allow us to "grab" only part of reality, but no one method can do it completely. So, all methods are applied comprehensively. 


\section{Results}

The novelty of this research is that this work analyzed problems of formation and realization of "the right to oblivion" in Russian in complex. One of the main results of generalization and systematization of problematic issues were formulated proposals for practical and theoretical perspectives of "the right to oblivion".

\section{Discussions}

\section{Discussions and practical applicability}

The so-called "right to oblivion" was firstly formulated in May 13, 2014 by European Court of Human Rights. The decision of European Court of Human Rights has not only divided Europe and the United States on the issue of this right, but it also initiated a heated discussion in Russia. Serious discussion broke out in the Federal Assembly of the Russian Federation, the Russian Public Chamber, Roskomnadzor, and in society.

What is the essence of the matter? In our view it is to find a balance between the individual's right to privacy and the right to free flow of information. Until recently, the right to free flow of information has dominated the individual's right to privacy. Now, perhaps, everything has changed. Therefore it is necessary to turn to Mario Kosteha Gonzalez' case at the suit to Google in European Court of Human Rights. At the time of M. K. Gonzalez's proceedings, in Spain there were more than 180 similar cases that were consolidated with M. K. Gonzalez' s case into one and were reviewed by European Court. The background of this case was the following: "In 2010, Gonzalez appealed to the local court to remove a message about auction sale of his house that was published on the Internet in 1998. The message told about sale for debts of the real estate owned by Gonzalez. This debt was repaid a long time ago, and the article was still there on the Internet, while the plaintiff considered that the reference in the search engine contained compromising him personal data. The Spanish authorities obliged Google to remove a link at the newspaper from the search engine, but declined to delete the text, since this information was posted on the website lawfully. Google, in its turn, appealed against the decision, believing that "it [was] an unfair decision, which challenges neutrality and transparency of the search." Spanish Supreme Court chose to convey this complex and controversial matter to European Court.

The judges of European Court concluded that "the right to oblivion" before the issuance of this decision was laid down in Directive 95/46 / EC on personal data protection. They drew attention to the fact that information, which used to be published by law, may become outdated over time, become incorrect or get a rebuttal and thus may cease to comply with the law. Collection and storage of information by search engines was regarded by the court as processing of information. The court considered search engines as a means of monitoring information in accordance with data protection laws in European countries in which the search engine is engaged in promoting advertising. Google, therefore, was required to eliminate the connection, which was secured in the retrieval system, between the site of the newspaper La Vanguardia and Gonzalez, despite the fact that back in 1998 the note was posted on the pages of the magazine without breaking the law. The result could have been different, according to the court, if disputed information had any public importance and public interest in it outweighed the applicant's personal desire to delete the data. Thus, the decision of European Court gives citizens the right, by analogy with Gonzalez's case, turn to search engines (and to any) in order to remove certain references concerning personal information about applicants. If the request is justified and there are no obstacles to its implementation, the search engine is obliged to grant the request. The data can remain on the site, in court documents in network archives, but since the search engine tears off the connection with the data, it will be extremely difficult to find them - only by incredible chance or you know where to look for them.

From now, anyone has the right to forbid Google distribute appropriate (or no longer correspond to reality) information. To this end, European sites of Google posted the form that the user must fill in to request deletion of data about him. In this form you can find user's name and specific URL, you have to attach a copy of the photo of your identity documents. This form is only available to Europeans. For the first four days of this new service, the company received 41,000 requests - around seven per minute. According to official information (Google), in November 2014 over 145 thousand people in the EU applied to this company, about half a million of references were under checks. Most requests came from users in France $(29,000)$, Germany $(25,000)$ and Great Britain $(18,000)$. These users' requirements seemed to be reasonable and logical, but Internet companies were not thrilled by the prospect of losing their income. It is known that transnational social networks and services (Google, Facebook, etc.) sell users' personal information to advertisers, enabling targeted advertising be aimed at specific people based on their interests and social status. Moreover, social networks, hiding behind technical difficulties, refused to delete users' photos and other materials which remained available for direct links and search engines, despite the fact that these users were confident in their destruction.

Not surprisingly, the US company Google negatively assessed this decision. "For each application we have to 
relate the individual's right to oblivion with the public's right to information. We want to achieve the right balance. This is a new and difficult thing for us, so we're looking for advice what principles to follow in order to find a right solution in each case," - is said in Google statement.

Lee Rowland, a lawyer from the American Civil Liberties Union, believes that implementation of these standards in the US is unlikely. "The First Amendment to the US Constitution guarantees the solid defense of freedom of the press and publishing information in the public domain", - he explains. "As a result, [this decision] the Internet will become fragmented and will use different rules and management models in different countries."

Another difficulty is to determine what information removal is justified, and what - is not. For example, whether the businessman has the right to delete the data about his bankruptcy, which occurred ten years ago? Can future politician hide information about his arrest, which, as he believes, was as the insignificant mistake of his violent youth? Opponents of these innovations fear that the court decision does not allow managing information properly. "This ruling will give largescale private censorship in Europe" - says James Waterswort, head of Brussels office of Computer and Communications Industry Association - the legal organization representing the interests of computer and information companies, including Facebook, Microsoft and Google. "Although the decision is intended to protect, we fear that they will be able to abuse policy and other people who have something to hide," - he says.

Initially, all experts regarded this decision as devastating for online businesses. After all online commerce today is built on contextual advertising and shaping consumer-user profile. This technology is continually being improved. If everyone in his sole discretion can remove unpleasant information about him, the portrait will not work reliably. But it was not so scary. The information itself remains on the server, where it is available - Google eliminates the link to it from its requests. In addition, European Court does not operate in the US, so curious people can simply go to the US site of this search engine.

The court's decision has also got a special clause: it does not protect "the right to oblivion" of public figures; information about their personal life is in considerable public interest.

Meanwhile, in Russia, this aspect of the judicial act does not get attention, and during discussion in the Public Chamber of the Russian Federation, prominent public figures understood this right - "the right to oblivion" in relation to public figures. To illustrate this approach, we can look at singer E. Gurtskaya' speech. Singer Diana Gurtskaya told a story when one journalist wrote a terrible story about her. Diana's parents didn't know that she could not see since she was five years old, when she fell off the couch and hit her forehead. The article was published over 10 years ago, but with the help of search engines it is easy to find it today. "I still feel discomfort", - says Diana Gurtskaya.- "Wherever I come, and during interviews all journalists ask me about this fact. First, this article shows that my parents were not good ones. Secondly, this story is not true, I do not want it to be in the public domain."

Solution of this question was under high discussion in Russia. The Public Chamber suggested allowing deleting personal data from search engines in Russian. It recommended the State Duma to support the decision of European Court. In Russia, "the right to oblivion" is considered much wider than by European Court of Human Rights. In our country, "the right to oblivion" is seen not only in relation to Internet search engines and social networks.. Full implementation of citizens' right to oblivion is complicated by the fact that foreign Internet giants do not have representative offices in Russia, which could take legally significant decisions. Overall Roskomnadzor supports public debate of the idea, but it requires taking into account legal and market realities.

During the discussion of "the right to oblivion" in Russia, members of the Public Chamber of the Russian Federation raised the issue of "freedom of speech". According to experts, in the case of search engines the question of censorship is not worth it. "Search engines were removed from the media". - reminds Leonid Levin, First Deputy Chairman of the Duma Committee on Information Policy, Information Technology and Communications. "It is noted that search engines are not the media, they are only engaged in aggregation of information, so protection of freedom of speech cannot be spread on them".

Another problem - how the search engine will determine if information, contained under the link, is false. "There are two problems." - says Irina levova, Head of Strategic Research of Russian Association of Electronic Communications. "First of all - how the search engine can determine whether this information is true or not? Secondly - the problem of identifying the person. The search engine is not able to determine whether it is really the person about whom this information is available, or it could be another person."

The Public Chamber of deputies recommended developing laws that protect personal data of Russian Internet users. The idea was supported by Leonid Levin, First Deputy Chairman of the Duma Committee on Information Policy, Information Technology and Communications: "We want to consider the decision of European Court, and to explore the possibility of its application in Russia. We should allow Russian people to protect their rights on the Internet." According to Levin, the regulation should concern not only Russian but also foreign search engines: if the service is distributing 
advertisements in Russian, users should be able to delete their data.

Citizens can require in court to remove personal information from the Internet. There are no precedents in Russia yet, so Roskomnadzor uses data protection mechanisms, based on pre-trial decisions and self-regulation. The practical significance of this research. The results of this research can be used in practical work of state and municipal governments and international organizations in addressing issues related to human rights. This work may also be useful to non-governmental organizations whose activities are aimed at promoting and protecting human rights. In addition, theoretical conclusions of this research can be used in research institutes as well as institutions of higher education teaching individual sections of discipline "Human Rights", as well as special courses of jurisprudence - legal regulation of technology and protection of private data.

\section{Conclusion}

Due to the fact that the European Convention on Human Rights is ratified in Russia, the decision of European Court of Human Rights can be implemented in Russian legislation. It could be amendments to the law on personal data, or the Civil Code. Today, the decision of European Court of Human Rights concerns only residents of the European Union. The question - how it will be adapted to Russian law - can be solved through judicial acts of the Supreme Court.

\section{Acknowledgements}

The authors express their gratitude to Director of Law Institute of Samara State University of Economics, Doctor of Law, Professor, A. A. Pavlushina, and Doctor of Law, Professor, V. V. Bolgova, for their valuable criticism and support.

\section{References}

Abarinov, B. The right to oblivion // Internet resource: http://www.svoboda.org/content/article/25437078.html, 13.04.2015.

Golitsyn, A. Search Engines will not remember // Internet resource: http://www.vedomosti.ru/newspaper/articles/2014/06/16/poiskovikine-pripomnyat, 16.06.2014.

Lakeeva, E. Europe received "the right to oblivion": there are a lot of dissatisfied// online resource: http://pravo.ru/interpravo/practice/ view/105053/, 14.05.2014.

Nersesian, T. Runet users get "the right to oblivion" // website:http://www.vesti.ru/doc.html?id=1677165, 12.06.2014.

The Russians will have "the right to oblivion" // Internet resource: http://www.dni.ru/tech/2014/11/6/285507.html, 06.11.2014.

Smirnov, S. Google asked users to help with the right to oblivion // Internet resource: http://www.vedomosti.ru/business/articles/ 2014/07/11/google-poprosil-polzovatelej-pomoch-s, 11.07.2014. 